12 Dekker C, Dales R, Bartlett S, Brunekreef B, Zwanenburg H. Childhood asthma and the indoor environment. Chest 1991; 100: 922-6.

13 Infante-Rivard C. Childhood asthma and indoor environmental risk factors Am F Epidemiol 1993; 137: 834-44.

14 von Mutius E, Fritzsch C, Weiland SK, Röll G, Magnussen H. Prevalence of asthma and allergic disorders among children in united Germany: a descriptive comparison. BMF 1992; 305: 1395-9.

15 Wjst M, Reitmier P, Dold S, et al. Road traffic and adverse effects on respiratory health in children. $B M F$ 1993; 307: 596-600.

16 Bråbåck L, Breborowicz A, Dreborg S, Knutsson A, Pieklik H, Björkstèn B. Atopic sensitization and respiratory symptoms among Polish and Swedish school children. Clin Exp Allergy 1994; 24: 826-35.

17 Corbo GM, Forastiere $\mathrm{F}$, Dell'Orco $\mathrm{V}$, et al. Effects of environment on atopic status and respiratory disorders in children. $\mathcal{F}$ Allergy Clin Immuno 1993; 92: 616-23.

18 von Mutius E, Martinez FD, Fritzsch C, Nicolai T, Reitmier P, Thiemann H-H. Skin test reactivity and number of siblings. $B M \mathcal{F} 1994$ 308: $692-5$.

19 Nitta H, Sato T, Nakai S, Maeda K, Aoki S, Ono M. Respiratory health associated with exposure to automobile exhaust. I. Results of crosssectional studies in 1979, 1982, and 1983. Arch Environ Health 1993; 48: 53-8.

20 Austin JB, Russell G, Adam MG, Mackintosh D, Kelsey S, Peck DF Prevalence of asthma and wheeze in the Highlands of Scotland. Arch Dis Child 1994; 71: 211-6.
21 Muranaka M, Suzuki S, Koizumi K, et al. Adjuvant activity of dieselexhaust particulates for the production of IgE antibody in mice. $\mathcal{F}$ Allergy Clin Immunol 1986; 77: 616-23.

22 Takafuji S, Suzuki S, Koizumi K, et al. Diesel exhaust particulates inoculated by the intranasal route have an adjuvant activity for IgE production in mice. $\mathcal{f}$ Allergy Clin Immunol 1987; 79: 639-45.

23 Riedel F, Kramer M, Scheibenbogen C, Rieger CH. Effects of $\mathrm{SO}_{2}$ exposure on allergic sensitization in the guinea pig. $\mathcal{f}$ Allergy Clin Immunol 1988; 82: 527-34.

24 Yanai $M$, Ohrui $T$, Aikawa $T$, et al. Ozone increases susceptibility to antigen inhalation in allergic dogs. $\mathcal{f}$ Appl Physiol 1990; 68: 2267-73.

25 Biagini RE, Moorman WJ, Lewis TR, Bernstein IL. Ozone enhancement of platinum asthma in a primate model. Am Rev Respir Dis 1986; 134: platinum

26 Rusznak C, Devalia JL, Davies RJ. The impact of pollution on allergic disease. Allergy 1994; 49: 21-7.

27 Abramson $M$, Voigt T. Ambient air pollution and respiratory disease. Med f Aust 1991; 154: 543-53.

$28 \mathrm{Kehrl} \mathrm{HR,} \mathrm{Vincent} \mathrm{LM,} \mathrm{Kowalsky} \mathrm{RJ,} \mathrm{et} \mathrm{al.} \mathrm{Ozone} \mathrm{exposure} \mathrm{increases} \mathrm{res-}$ piratory epithelial permeability in humans. Am Rev Respir Dis 1987; 135: $1124-8$

29 Matsumura Y. The effects of ozone, nitrogen dioxide and sulfur dioxide on the experimentally induced allergic respiratory disorder in guinea pigs. II. The effects of ozone on the absorption and the retention of antigen in the lung. Am Rev Respir Dis 1970: 102: 438-43.

\title{
Guidelines for the administration of blood products
}

Earlier this year a document setting out guidelines for the administration of blood products to infants and neonates was published under the authorship of a working party of the British Committee for Standards in Haematology (BCSH) Blood Transfusion Task Force. ${ }^{1}$ These guidelines are the first of their type to be produced in the UK and are to be welcomed. Unfortunately their publication in a specialist transfusion journal has probably meant that they may not have reached a wider paediatric audience.

The authors acknowledge that many accepted practices are not founded wholly on objective investigation. We are uneasy about 'broad agreement' as a basis for firm recommendations. Many would view consensus medicine as a reduction to the lowest common denominator and one which stifles leading edge changes in practice. We believe that a set of guidelines should draw attention to evidence based recommendations but that an important additional role is to highlight uncertainties.

\section{Evidence based recommendations}

In these guidelines some very useful, clear statements are made, with well referenced substantiating evidence. These include widely accepted views such as that walking donor panels are no longer considered appropriate as a source of blood for neonatal transfusions. Others are based on sound evidence but are less widely appreciated, such as that red cell components may safely be used to the end of their full shelf life for small volume neonatal transfusions. ${ }^{2}$ Similarly, the use of satellite packs are an effective means by which to reduce donor exposure in extremely preterm neonates but only if the hospital transfusion laboratory uses them appropriately to the end of their shelf life and ensures the allocation of units to particular infants. ${ }^{3}$ The guidelines set out a clear pretransfusion testing protocol for neonates. This includes an indirect antiglobulin test to exclude atypical antibodies, and emphasises that further screening for red cell antibodies is unnecessary for the first four months after birth. This deserves wide publicity in service laboratories, particularly to those providing on-call services to neonatal units.

\section{Red cell transfusion}

The guidelines also briefly review the indications for red cell transfusions, a contentious area, on which there is an extensive literature. However, no mention is made of the use of erythropoietin, which may change transfusion requirements. ${ }^{4}$ The reader is referred to a recent review of the subject by Luban. ${ }^{5}$ Some uncertainties might have merited more critical discussion. Two prospective studies describe the inability of infants to develop alloantibodies, ${ }^{67}$ and this provides the justification for advising that repeat red cell antibody screening is unnecessary for four months. However, what is the effect of preterm birth on the ability to react to allogeneic red cell antigens? Is the 'first 4 months of age' the same in immunological terms for an infant born at 24 weeks as for one born at 36 weeks? Is there any evidence that birth matures the ability to form red cell alloantibodies and what are the effects of fetal transfusion on the alloimmune process?

\section{Intrauterine transfusion}

It might have been appropriate to have extended the initial brief, to include transfusion of the fetus. In many ways the conceptual division between the fetus and neonate is artificial. Immunological naivety, the ability, or the inability, to react to an alloimmune stimulus, susceptibility to viral infections, and potentially long post-transfusion survival, are shared by both groups of patients. Delayed side effects relating to intrauterine transfusion may be dealt with by neonatal paediatricians and may include suppression of erythropoiesis, transfusion transmitted infection, possible induction of immune tolerance, and transfusion associated graft versus host disease (TA-GVHD).

\section{Graft versus host disease}

The risk of TA-GVHD in fetal and neonatal transfusion practice is small but finite and may be associated with immune naivety and the proportionately large, fresh transfusions containing viable lymphocytes that these tiny patients may receive. There are very few reported cases of neonatal TA-GVHD and this may reflect its rarity, under 
reporting, or the already established practice of gamma irradiation which is the only effective method of prevention of this virtually uniformly fatal complication of transfusion. There is definitely a need to irradiate all related directed donations ${ }^{89}$ and donations to infants with suspected or proved cellular immune deficiency. Other indications are more contentious. The guidelines suggest the use of irradiated products for intrauterine transfusions, any subsequent exchange transfusions such babies may receive, and exchange transfusions in very low birthweight babies. TA-GVHD after unrelated donor intrauterine transfusion alone has been described in only a single, controversial case report. ${ }^{10}$ It is unknown whether an intrauterine transfusion results in immunosuppression of the fetus leading to increased susceptibility to future TA-GVHD. The evidence appears to rest on four reported cases of an unrelated donation leading to TA-GVHD after exchange transfusion in immunologically normal neonates who had previously received intrauterine transfusions. ${ }^{11-13}$ Of these four cases, three were shown to be due to engraftment of lymphocytes from the exchange transfusion donor, which suggests a possible previous immunosuppressive effect of the intrauterine transfusion. The fourth case of TAGVHD appeared to be due to one of the donors whose blood was used twice for intrauterine transfusion. ${ }^{11}$ There have also been five reported cases of TA-GVHD after exchange transfusion alone. Three occurred in preterm infants ${ }^{14-16}$ and two were at term. ${ }^{1317}$ One case was described in Israel where the population is relatively homogenous, ${ }^{14}$ which may have increased the chance of an HLA match between donor and recipient. These cases of TA-GVHD must be viewed in the context of the thousands of exchange transfusions that have been performed. It therefore seems questionable to recommend irradiation of blood for exchange transfusion in very low birthweight babies, particularly as an effect of irradiation is to increase potassium egress from red cells.

\section{Irradiated blood products}

Gamma irradiation produces an increase in potassium egress from the red cells into the supernatant, which varies with the red cell concentration, the age of the red cells at the time of irradiation, and subsequent storage time. The potassium rise in the supernatant over the initial few days is greatest, falling away to approximately double the level in the non-irradiated counterpart for red cells in optimal additive solution, a component commonly used for top up transfusions. For red cells concentrated to a packed cell volume of 0.9 , as may be used in fetal transfusions, the initial rise is steeper. ${ }^{18}$ However, as the guidelines rightly acknowledge, the total potassium content of a small volume transfusion is small and blood used for top-up transfusion should therefore be used to the end of its shelf life. The authors go on to recommend that irradiated red cells should be used within four days of storage. However, unpublished data from the North London Blood Transfusion Centre shows that at four days, irradiated red cell units in optimal additive solution, as often used in topup transfusions, only contains $3 \mathrm{mmol}$ of potassium compared with $1 \mathrm{mmol}$ per unit in the unirradiated counterpart. The neonatal guidelines also recommend that unirradiated blood for exchanges and other large transfusions should be used within five days of collection but that irradiated blood should be used within 24 hours. This may be overly cautious. Further unpublished data from the North London Blood Transfusion Centre shows that the total potassium content per unit of irradiated whole blood is only $4.2 \mathrm{mmol}$ by day 4 , compared with $2 \mathrm{mmol}$ per unirradiated unit.

\section{Filtration}

The place of filtration might have usefully been clarified, particularly for a non-specialist readership. Microaggregate filters have not been shown to be beneficial in small volume transfusions for neonatal subjects. It is recommended that large volume transfusions and transfusions to critically ill infants should be filtered, although evidence of benefit is lacking. Filtration may also be used for leucodepletion. Increasingly leucodepletion is being performed by transfusion centres before issuing blood products rather than at the bedside. There is now evidence that multiply transfused infants below 36 weeks can, transiently, develop anti-HLA antibodies after as few as three transfusions. ${ }^{19}$ The clinical long term relevance of these antibodies is not known, nor of the immunological effects and induction of tolerance of repeated antigen loads and multiple transfusions from the same donor, as occurs with the use of multiple satellite packs. Leucodepletion may prevent some of these immunological effects of transfusion as well as the transmission of white cell associated organisms such as human $T$ cell leukaemia virus and cytomegalovirus. However, filters are not yet capable of reducing the while cell content of components enough to prevent TA-GVHD. Further study of leucodepletion of components for neonatal transfusion should be encouraged.

\section{Current clinical practices}

FEAR OF TRANSFUSION OVERLOAD

Regrettably certain widespread, but unjustified practices in neonatal medicine are uncritically reinforced. In the UK it appears to be a common practice to follow transfusions of packed red blood cells in neonates with an injection of frusemide. However, there are no reported cases of overload in electively transfused preterm babies. Atrial natriuretic peptide release is triggered by vascular overload and no increase was demonstrated when preterm infants were transfused slowly with $10 \mathrm{ml} / \mathrm{kg}$ of packed red cells. ${ }^{20}$ In severe, chronic, euvolaemic anaemia, as may occur for example after chronic fetomaternal or twin to twin transfusion, a partial exchange transfusion with a red cell concentrate may be advisable rather than a top-up transfusion with frusemide cover. Present day practice is for top-up transfusions to consist of red cell concentrates with an adjusted packed cell volume ideally to $0 \cdot 5-0 \cdot 7$. Polycythaemia, rather than volume overload, after red cell transfusion, may be a greater hazard in the newborn. Though this is a particular problem when excessively plasma reduced preparations are used inappropriately for exchange transfusions, there may be wider implications such as an increased risk of necrotising enterocolitis. ${ }^{21}$ It is conceivable that an increase in blood viscosity may further impair perfusion in already compromised bowel.

A single dose of frusemide leads to a substantial increase in sodium excretion. Many preterm babies are in precarious sodium balance and chronic sodium depletion is an important cause of growth failure. ${ }^{22}$ Frusemide is also a potent calciuric agent and repeated doses will contribute to the development of osteopenia of prematurity and nephrocalcinosis. Ductal patency, through the effect on renal prostaglandin $E_{2}$ production, ${ }^{23}$ and ototoxicity are other potential hazards of frusemide use.

The majority of newborn babies receiving top-up red cell transfusions are not in heart failure. The situation may, however, be different from infants with bronchopulmonary dysplasia, in whom heart failure is not uncommon, although published data, supporting the use of diuretics, are not convincing. ${ }^{2425}$ In the case of transfusions in infants with overt heart failure the logical approach would be to reduce the rate of transfusion to $2 \mathrm{ml} / \mathrm{kg} / \mathrm{hour} .{ }^{26}$ 
FRESH FROZEN PLASMA OR HUMAN ALBUMIN SOLUTION A further area of controversy in neonatal practice concerns the indications for the use of fresh frozen plasma. Both fresh frozen plasma and human albumin solution are widely used in neonatal intensive care units. ${ }^{27}$ It is accepted that fresh frozen plasma is not a suitable product for volume expansion in adults or children, ${ }^{28} 29$ but there are some grounds for questioning the extrapolation to extremely immature neonates. The need for volume expansion often occurs in babies who are septic and may also have a coagulopathy. The diagnosis of both these conditions is often difficult. If volume expansion is necessary it should be carried out without delay. Fresh frozen plasma, unlike human albumin solution, contains coagulation factors and the naturally occurring anticoagulant factors, as well as opsonins, and there is evidence that fresh frozen plasma may enhance neonatal neutrophil chemotaxis. ${ }^{30}$ However, while the manufacture of human albumin solution carries viral inactivation steps, viral transmission by fresh frozen plasma poses a small but finite risk. ${ }^{27}$ There is an urgent need for scientific study of the possible benefits of these two agents and comparison with other colloids. Moves to increase the microbiological safety of fresh frozen plasma include viral inactivation and the use of plasma from well characterised donors.

\section{IMMUNOTHERAPY}

The section on granulocyte treatment has suffered from oversimplification. Though there appears to be some evidence of benefit (though not from random donor buffy coats!), the practical and technical problems of transferring granulocytes from donor to patient quickly, effectively and repeatedly, make it beyond the reach of all but a few neonatal centres. The availability of the recombinant cytokines, granulocyte and granulocyte-monocyte colony stimulating factor may circumvent these problems and open up exciting possibilities for the enhancement of neonatal immune functions. ${ }^{31}$

\section{Register of rare conditions}

A number of rare, but serious side effects of transfusion and errors in transfusion practice may be recognised by paediatricians. Examples include the incidence of cytomegalovirus pneumonitis in preterm infants, TAGVHD, the incidence of $T$ activation and problems of hyperkalaemia in infants undergoing large volume transfusions, particularly with irradiated red cell products. Similarly, rare disorders such as alloimmune neonatal thrombocytopenia may be better recognised and appropriately managed if awareness is increased by inclusion in a reporting system. The medical director of the National Blood Authority, or the British Paediatric Surveillance Unit would be appropriate bodies to collate such data and to utilise it to best effect.

\section{Future guidelines}

Any set of guidelines needs regular revision. The outcomes of current clinical trials evaluating the use of growth factors, immunological enhancement treatments, and the use of specific blood components for neonatal use, are likely to change neonatal transfusion practices over the next few years. We look forward to future updates from the British Committee for Standards in Haematology Blood Transfusion Task Force.
North London Blood Transfusion Centre,

RUTH WARWICK

Colindale Avenue,

London NW9 5BG

Royal Postgraduate Medical School,

NEENA MODI

Hammersmith Hospital,

DuCane Road,

London W12 ONN

We thank Mrs Denny Williams for patiently and accurately typing the manuscript.

1 BCSH Blood Transfusion Task Force. Guidelines for the administration of blood products: transfusion of infants and neonates. Transfusion Medicine 1994; 4: 63-9.

2 Wood AE, Tidmarsh CE, Wilson N, et al. Top up transfusions in premature neonates reducing donor exposure. Br f Haematol 1993; 84 (suppl 1): 46.

3 de Silva M, Wijayatilake S, Fehily D. An audit of neonatal red cell transfusions in seven London special baby care units. $\mathrm{Br} \mathcal{F}$ Haematol 1993; 84 (suppl 1): 46

4 Maier RF, Obladen M, Scigalla $P$, et al. The effect of epoetin beta (recombinant human erythropoietin) on the needs for transfusion in very-lowbirth-weight infants. N Engl f Med 1994; 330: 1173-8.

5 Luban NL. Review of neonatal red cell transfusion practices. Blood Rev 1994; 8: 148-53.

6 Ludvigson CW, Swanson JL, Thompson JR, McCullough J. The failure of neonates to form red blood cell alloantibodies in response to multiple transfusions. Am $\mathcal{F}$ Clin Pathol 1987; 87: 250 .

7 Floss AM, Strauss RG, Goeken N, Knox L. Multiple transfusions fail to provoke antibodies against blood cell antigens in human infants. Transfusion 1986; 2: 419

8 Kanter MH. Transfusion-associated graft-versus-host disease: do transfusions from second-degree relatives pose a greater risk than those from first-degree relatives? Transfusion 1992; 32: 323-7.

9 McMilin KD, Johnson RL. HLA homozygosity and the risk of relateddonor transfusion-associated graft-versus-host disease. Transfus Med Rev 1993; 7: 37-41.

10 Jan-Mohamed R, Hambley H, Gamsu H, Mufti GJ. Transfusion associated graft versus host disease - experience in a single centre. $\mathrm{Br} \mathcal{F}$ Haematol 1993; 84 (suppl 1): 10.

11 Naiman JL, Punnett HH, Lischner HW, Destiné ML, Arey JB. Possible graft-versus-host reaction after intrauterine transfusion for $\mathrm{Rh}$ erythrograft-versus-host reaction after intrauterine transf
blastosis fetalis. $N$ Engl $\mathcal{F}$ Med 1969; 281: $697-701$.

12 Parkman R, Mosier D, Umansky I, Cochran W, Carpenter CB, Rosen MD. Graft-versus-host disease after intrauterine and exchange transfusions for Graft-versus-host disease after intrauterine and exchange transfusions
hemolytic disease of the newborn. N Engl f Med 1974; 290: 359-63.

13 Böhm N, Kleine W, Enzel U. Graft-versus-host disease in two newborns after repeated blood transfusions because of rhesus incompatibility. Beitr Path 1977; 160: 381-400.

14 Flidel O, Barak Y, Lifschitz-Mercer B, Frumkin A, Mogliner BM. Graft versus host disease in extremely low birth weight neonate. Pediatrics 1992; 89: 689-90.

15 Hathaway WE, Brangle RW, Nelson TL, Roeckel IE. Aplastic anaemia and alymphocytosis in an infant with hypogammaglobulinaemia: graft-versushost reaction? F Pediatr 1966; 68: 713-22.

16 Seemayer TA, Bolande RP. Thymic involution mimicking thymic dysplasia. Arch Pathol Lab Med 1980; 104: 141-4.

17 Lauer BA, Githens JH, Hayward AR, Conrad PD, Yanagihara RT, Tubergen DG. Probable graft-versus-graft reaction in an infant after exchange transfusion and marrow transplantation. Pediatrics 1982; 70: 43-7.

18 Warwick R, Vickers M, Penny S, Harris C, Seghatchian J, Stivala J. Characteristics of red cell components irradiated by the IBL 137 irradiator. British Blood Transfusion Society XII Annual Scientific Meeting irradiator. British Blood 4 (suppl 1): 28.

19 Bedford Russell AR, Rivers RPA, Davey N. The development of anti-HLA antibodies in multiply transfused preterm infants. Arch Dis Child 1993; 68: 49-51.

20 Rascher W, Lingens N, Bald M, Linderkamp O. Atrial natriuretic peptide and blood volume during red cell transfusion in preterm infants. Arch Dis Child 1991; 66: 395-7.

21 McGrady GA, Rettig PJ, Istre GR, Jason JM, Holman RC, Evatt BL. An outbreak of necrotizing enterocolitis: association with transfusions of packed red blood cells. Am $\mathcal{F}$ Epidemiol 1987; 126: 1165-72.

22 Haycock GB, Aperia A. Salt and the newborn kidney. Pediatr Nephrol 1991; 5: $65-70$.

23 Green TP, Thompson TR, Johnson DE, Lock JE. Furosemide promotes patent ductus arteriosus in premature infants with the respiratory-distress patent ductus arteriosus in premature infants

24 Stefano JL, Bhutani VK. Role of furosemide therapy after booster packed erythrocyte transfusions in infants with bronchopulmonary dysplasia. $\mathcal{f}$ Pediatr 1991; 117: 965-8.

25 O'Donovan BH, Bell EF. Effects of frusemide on body water compartments in infants with bronchopulmonary dysplasia. Pediatr Res 1989; 26: 121-4. 26 DePalma L, Luban NLC. Blood component therapy in the perinatal period: guidelines and recommendations. Semin Perinatol 1990; 14: 403-15.

27 McClure G. The use of plasma in the neonatal period. Arch Dis Child 1991; 66: 373-5.

28 BCSH Working Party of the Blood Transfusion Task Force. Guidelines for the use of fresh frozen plasma. Transfusion Medicine 1992; 2: 57-63.

29 National Institutes of Health Consensus Conference. Fresh frozen plasma: indications and risks. $\mathcal{F} A M A$ 1985; 253: 551-3.

30 Eisenfeld L, Krause PJ, Herson VC, Block C, Schick JB, Maderazo E. Enhancement of neonatal neutrophil motility (chemotaxis) with adult fresh frozen plasma. Am $\mathcal{f}$ Perinatol 1992; 9: 5-8.

31 Westwood NB, Chung R, Emmerson AJB, Pearson TC. The in vitro effects of stem cell factor, interleukin 3 and granulocyte-macrophage colony stimulator factor onhaemopoietic progenitor cells from premature infants. Br f Haematol 1994; 86: 468-74. 